\title{
ANÁLISE PARA REQUALIFICAÇÃO DE ESPAÇOS LIVRES NA UFSC
}

\section{FERNANDA WERLICH DOS PASSOS | UFSC CARLOS EDUARDO VERZOLA VAZ, Ph.D |UFSC}

\section{INTRODUÇÃO}

A universidade é um espaço importante para o desenvolvimento intelectual e social, nela há oportunidades para promover a reunião de grupos, por ser acessível a todos os níveis sociais, e por possibilitar uma cidadania inclusiva.

A desconexão dos elementos físicos e dos significativos (KENNEY D., KENNEY G., DUMONT, 2005) na universidade ressaltam a falta de legibilidade de determinados espaços; a demarcação de estacionamentos e a crescente proliferação de edificações "sem comunicação" contradizem o potencial do ambiente universitário. Com isso, o senso de comunidade é dificultado.

Dentro desse cenário, o campus da UFSC é um recorte urbano marcado pela crescente demanda de construções ao longo dos anos e, somado a um planejamento ineficaz, colaborou para o surgimento de diversos problemas de qualidade nas construções e nos seus espaços abertos.

Diante disso, quais diretrizes contribuem para ambientes de aprendizagem nos espaços abertos do campus? Entender as maneiras de gerar inovação no campus seja no espaço aberto ou edificado contribuem para melhorar a comunicação entre as pessoas e gerar novas ideias.

\section{OBJETIVOS}

O objetivo geral do estudo é a investigação dos espaços livres da Universidade Federal de Santa Catarina para requalificar as relações de estudantes, professores, funcionários e comunidade na universidade.

Além disso, o estudo apresenta como objetivos específicos (a) compreender a importância de favorecer a humanização do campus, a fim de entender os maiores fluxos das pessoas na universidade, (b) definir recortes do campus para analisar seus espaços abertos mais utilizados.

\section{DEFINIÇÃO DOS RECORTES E ANÁLISE}

Para avaliar os usos do espaço da UFSC, foi usado como base o mapeamento dos principais fluxos de movimento das pessoas. Com isso, três recortes ((1) leste da região central da UFSC, (2) região central e (3) oeste da região central) foram feitos baseados no caminhar para documentar os principais fluxos.

Após feitos os recortes, foram levantadas algumas diretrizes para analisar em conjunto, sendo elas: habilidades e competências (amarelo), em relação à variedade de Centros, conexão humana e tecnológica (azul), em relação à conexão em cafés e gramados, espaços de aprendizagem (verde), em relação a ambientes flexíveis e versáteis e interdisciplinaridade (laranja), em relação às diferentes interações no espaço, seja nas quadras de esporte, seja nas salas de aula.

Foram dadas notas de um a cinco e, com isso, resultou no primeiro recorte como o mais carente de habilidades e competências, de conexão humana e tecnológica e de espaços de aprendizagem. Necessitando de uma intervenção para requalificar as relações no espaço.

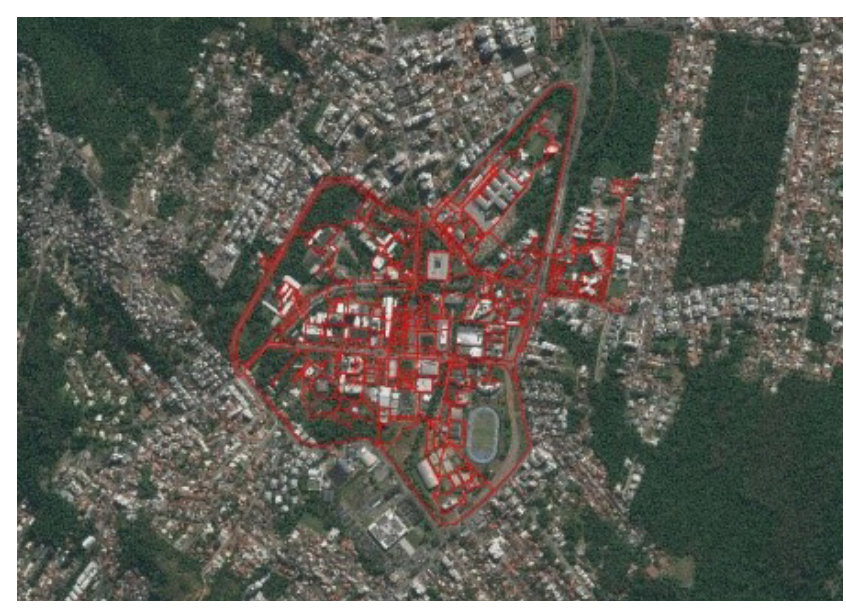

Figura 1 - Mapeamento dos fluxos de pessoas na UFSC (vermelho). Sem escala. Fonte: CRFP UFSC, 2020. 


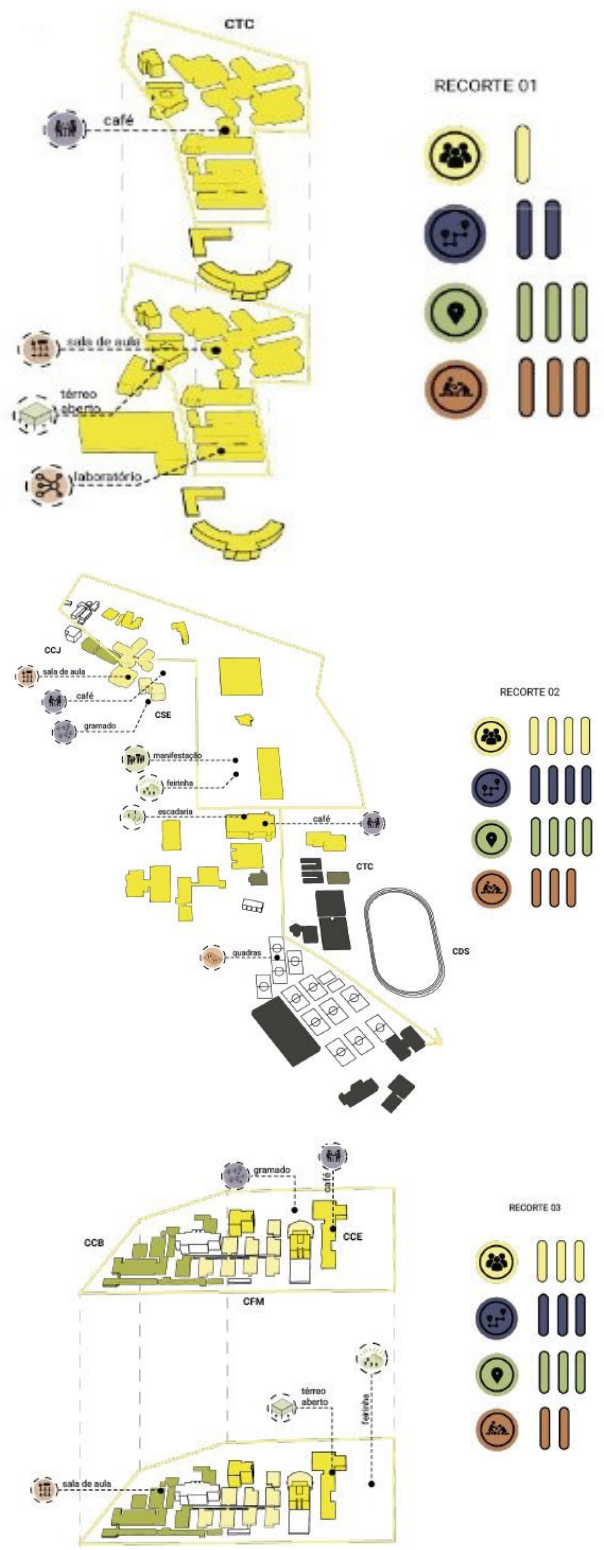

Figura 2 - Definição dos recortes e análise.

Fonte: Elaborado pela autora, 2020.

\section{REFERÊNCIA}

DUMONT, KENNEY D., KENNEY G. Mission and Place: Strengthening Learning and Community through Campus Design. American Council On Education, 2005 